\title{
Effect of Spraying Dolomite Nano-Particles on Growth, Flowering and Fruit Setting of Picual Olive (Olea europaea L.) Cultivar under Water Stress Conditions
}

\author{
I. M. Dobiea*1,2, H. E. M. El-Badawy ${ }^{1}$, S. F. El-Gioushy ${ }^{1}$, A. A. H. Hegazy ${ }^{2}$ \\ 1- Horticulture department, Faculty of agriculture, Benha University, Egypt. \\ 2- Plant Production department, Desert Research center, Egypt. \\ *_C Corresponding author: Ibrahimdobea9103@gmail.com
}

\begin{abstract}
Water stress "an abiotic stress" is one of the main challenges which constrain olive cultivation in reclaimed area in Egypt. It can impair the growth and production performance of olives. Many investigations recommended spraying dolomite nano-particles "Lithovit ${ }^{\circledR}$ fertilizer" to reduce the effect of water stress. We believe that we have designed an innovative solution to follow up the effect of spraying dolomite nano-particles $\left(\mathrm{Ca} \mathrm{CO}_{3} \& \mathrm{Mg}\right.$ $\mathrm{CO}_{3}$ ) on olive trees which exposure to different irrigation levels. Four concentrations of dolomite nano-particles were sprayed on olive (Olea europaea var. Picual) trees $(0,2,4$ and $6 \mathrm{~g} / \mathrm{L})$ under three irrigation levels $(50,75$ and $100 \%$ of evapotranspiration for crop "ETc") during 2017, 2018 seasons. Strong evidence of irrigation at $75 \%$ of ETc was found on olive growth, flowering and fruit setting. It was the best irrigation level to balance between vegetative growth and blooming. Moreover, there were significant variations between spraying dolomite nanoparticles at $2 \mathrm{~g} / \mathrm{L}$ and other concentrations on flowering and fruit setting. Furthermore, the interaction between spraying dolomite nano-particles and irrigation levels cleared that spraying dolomite nano-particles at $2 \mathrm{~g} / \mathrm{L}$ and irrigation at $75 \%$ of ETc enhanced flowering and fruit setting.
\end{abstract}

Keywords :- Olive, nano science, dolomite nano-particles "Lithovit ${ }^{\circledR}$ fertilizer" and water stress

\section{Introduction}

Olive trees have been widely cultivated throughout the Mediterranean basin for around 5000 years. Olives can thrive and produce in arid, semi-arid and the new reclaimed areas. As it can resist abiotic potentials such as drought, fluctuation in temperature, salinity Etc. (Xiloyannis et al., 1999 and Shaheen et al., 2011).

Previous studies indicated that water stress plays a major role in olives growth and productivity moreover, it impairs the performance of olives growth and production. Besides supplying olives with water requirements increase vegetative growth, flowering and yield quantity and quality. On the other side, vegetative growth, flowering and yield quantity and quality decrease gradually with increasing water stress (Lavee et al., 1990, Xiloyannis et al., 1999, Chartzoulakis et al., 2000, Asik et al., 2014 and Tangu, 2014).

Spraying dolomite nano-particles "Lithovit ${ }^{\circledR}$ fertilizer is natural stone which grinded in special mills and converted to fine powder" as foliar application leads to decompose its particles and release among other substances, especially calcium oxide $(\mathrm{CaO})$ and carbon di oxide $\left(\mathrm{CO}_{2}\right)$ at high concentration in the intercellular compartment inside the leaves as well as on leaves surface which penetrate directly through the stomata (Kumar et al., 2013). The process of elevate $\mathrm{CO}_{2}$ in intercellular compartment and on leave surface lead to close stomata and photosynthesis continue efficiently due to diffused carbon dioxide inside the leaves, so plant decrease transpiration rate and reduce water requirement due to high drought tolerance (Bunce, 2003, Carmen et al., 2014 and Ainsworth and Rogers, 2007). This study was initiated to follow up the effect of spraying dolomite nano-particles $\left(\mathrm{CaCO}_{3}\right.$ $\& \mathrm{Mg} \mathrm{CO}_{3}$ ) on Picual Olives growth, flowering and fruit setting under water stress conditions.

\section{Materials and methods}

This study was carried out at Wadi El-Natron in a sandy soil "Surface soil samples were taken and air dried for carrying out physical and chemical analysis which presented in the tables 1 and 2" of a private orchard at Wadi El-Natron, El Behera governorate, Egypt (30 31' 05" $\mathrm{N}$ and $30^{\circ}$ 07' 34" E). The experiment was started in December and continued during two successive growing seasons (2017\& 2018). It was investigated on Picual olive cultivar. Seventy-two bearing trees were selected and divided into 12 different treatments. Each treatment divided into three replicates and two trees for each of them. These selected trees were treated with three irrigation levels (50, 75 and $100 \%$ of ETc) and four concentrations of dolomite nano-particles "Lithovit ${ }^{\circledR}$ fertilizer" $(0,2,4$ and $6 \mathrm{~g} / \mathrm{L})$ were sprayed as a foliar application in the first week of February, May, August.

Table 1. Analysis of mechanical dry sieving of the orchard experimental soil.

\begin{tabular}{lccccccc}
\hline Texture & Depth & $\begin{array}{c}1-2 \\
\mathrm{~mm}\end{array}$ & $\begin{array}{c}\text { Coarse } \\
\text { sand }\end{array}$ & $\begin{array}{c}\text { Medium } \\
\text { sand }\end{array}$ & Fine sand & $\begin{array}{c}\text { Very fine } \\
\text { sand }\end{array}$ & $\begin{array}{c}\text { Silt }+ \\
\text { Clay }\end{array}$ \\
\hline Sandy soil & $0-60 \mathrm{~cm}$ & 7.5191 & 15.3507 & 38.1163 & 32.182 & 6.4756 & 0.3563 \\
\hline
\end{tabular}


Table 2. chemical analysis of the orchard experimental soil.

\begin{tabular}{|c|c|c|c|c|c|c|c|c|c|c|}
\hline $\mathrm{Ca}^{++}$ & $\mathrm{Mg}^{++}$ & $\mathrm{Na}^{+}$ & $\mathrm{K}^{+}$ & $\mathrm{CO}_{3}^{--}$ & $\mathrm{HCO}_{3}{ }^{-}$ & $\mathrm{Cl}^{-}$ & $\mathrm{SO}^{--}$ & $\mathrm{PH}$ & $\mathrm{EC}$ & TDS \\
\hline \multicolumn{8}{|c|}{$\mathrm{meq} / \mathrm{L}$} & \multirow{2}{*}{7.6} & $\mathrm{dS} / \mathrm{m}$ & $\mathrm{mg} / \mathrm{L}$ \\
\hline 25.988 & 2.518 & 5.218 & 0.383 & Nil & 0.42 & 30.389 & 4.828 & & 3.34 & 2333.4 \\
\hline
\end{tabular}

The following table presented chemical analysis of irrigation water sample, which taken from a well after two hours of starting operating.

Table 3. Chemical analysis of irrigation water simple.

\begin{tabular}{|c|c|c|c|c|c|c|c|c|c|c|}
\hline $\mathrm{EC}$ & TDS & $\mathrm{PH}$ & $\mathrm{Ca}^{++}$ & $\mathrm{Mg}^{++}$ & $\mathrm{Na}^{+}$ & $\mathrm{K}^{+}$ & $\mathrm{CO}_{3}{ }^{--}$ & $\mathrm{HCO}_{3}^{-}$ & $\mathrm{SO}_{4}^{--}$ & $\mathrm{Cl}^{-}$ \\
\hline$\mu \mathrm{S} / \mathrm{cm}$ & $\mathrm{Mg} / \mathrm{l}$ & \multirow{2}{*}{7.7} & \multicolumn{4}{|c|}{ Cations $\mathrm{meq} / \mathrm{l}$} & \multicolumn{4}{|c|}{ Anions meq/l } \\
\hline 1617 & 641.5 & & 1.638 & 1.467 & 8.696 & 0.077 & 0.799 & 2.599 & 0.262 & 7.668 \\
\hline
\end{tabular}

\section{Climatic data}

Meteorological data were investigated before conducting the experiments by using climwatt and cropwatt programs to calculate reference evapotranspiration and showed in tables 4 and 5 .
ETc calculated as follow:

$\mathbf{E T c}=\mathbf{E T o} \times \mathbf{K c}$

ETc: crop evapotranspiration

ETo: reference crop evapotranspiration

Kc: crop coefficient

Table 4. Meteorological data and ETo. in El Behera governorate.

\begin{tabular}{lcccccccc}
\hline & Min Temp. & Max Temp. & Humidity & Wind & Sun & Rad & $\begin{array}{c}\text { Eff. } \\
\text { rain }\end{array}$ & ETo \\
\cline { 2 - 9 } Month & ${ }^{\circ} \mathrm{C}$ & ${ }^{\circ} \mathrm{C}$ & $\%$ & $\mathrm{~km} / \mathrm{day}$ & hours & $\mathrm{MJ} / \mathrm{m}^{2} / \mathrm{day}$ & $\mathrm{mm}$ & $\mathrm{mm} / \mathrm{day}$ \\
\hline Jan. & 5.2 & 19.8 & 52 & 207 & 7.8 & 13.9 & 1 & 2.86 \\
Feb. & 6.6 & 21.8 & 44 & 242 & 8.6 & 17.1 & 1 & 3.89 \\
Mar. & 9.6 & 24.8 & 39 & 277 & 8.9 & 20.1 & 1 & 5.19 \\
Apr. & 13.8 & 30.7 & 31 & 277 & 9.3 & 22.8 & 1 & 6.95 \\
May & 17.5 & 34.5 & 29 & 268 & 10.3 & 25.3 & 0 & 8.05 \\
June & 20.3 & 36.9 & 31 & 277 & 11.2 & 26.9 & 0 & 8.84 \\
July & 21.3 & 37.1 & 36 & 225 & 11.1 & 26.5 & 0 & 8.01 \\
Aug. & 21.4 & 36.8 & 38 & 207 & 10.8 & 25.3 & 0 & 7.48 \\
Sep. & 19.4 & 34.4 & 43 & 216 & 9.9 & 22.1 & 0 & 6.50 \\
Oct. & 16.2 & 30.3 & 46 & 216 & 9.1 & 18.3 & 0 & 5.15 \\
Nov. & 10.6 & 25.5 & 51 & 181 & 8.4 & 14.9 & 0 & 3.55 \\
Dec. & 6.6 & 20.7 & 55 & 199 & 7.9 & 13.3 & 0 & 2.79 \\
\hline
\end{tabular}

Table 5. Kc and ETo. in BAHARIA, by using climwatt and cropwatt programs and FAO56.

\begin{tabular}{lcccrr}
\hline & $\begin{array}{c}\text { ETo } \\
\text { mm/day }\end{array}$ & Kc 1 & Kc 2 & $\begin{array}{c}\text { ETc 1 } \\
\text { mm/day }\end{array}$ & $\begin{array}{c}\text { ETc 2 } \\
\text { mm/day }\end{array}$ \\
\hline January & 2.86 & 0.50 & 0.50 & 1.43 & 1.43 \\
February & 3.89 & 0.50 & 0.50 & 1.945 & 1.945 \\
March & 5.19 & 0.65 & 0.65 & 3.3735 & 3.3735 \\
April & 6.95 & 0.68 & 0.60 & 4.69125 & 4.17 \\
May & 8.05 & 0.68 & 0.55 & 5.43375 & 4.4275 \\
June & 8.84 & 0.68 & 0.50 & 5.967 & 4.42 \\
July & 8.01 & 0.70 & 0.45 & 5.607 & 3.6045 \\
August & 7.48 & 0.70 & 0.45 & 5.236 & 3.366 \\
September & 6.50 & 0.70 & 0.45 & 4.55 & 2.925 \\
October & 5.15 & 0.70 & 0.65 & 3.605 & 3.3475 \\
November & 3.55 & 0.70 & 0.65 & 2.485 & 2.3075 \\
December & 2.79 & 0.70 & 0.65 & 1.953 & 1.8135 \\
\hline
\end{tabular}


Data of following parameters were recorded:

1 Vegetative growth characteristics

Five uniform shoots were randomly selected of each of main selected branches and labeled to record vegetative growth measurements.

\section{1 shoot length $(\mathrm{cm})$}

Average shoots length measured for the twenty shoots which selected at the end of the growing season of each replicated tree. The length of each shoot "between the points of new growth initiation to the tip of the shoot" was measured at the first week of March and at the last week of August and difference between these two observations was designated as shoot length of the season. It measured by ruler and expressed in centimeters $(\mathrm{cm})$.

\section{2 number of shoots per meter}

The average number of new shoots per meter of each replicated tree was counted at the end of the growing season.

\subsection{Leaf area $\left(\mathrm{cm}^{2}\right)$}

Samples of 20 adult leaves/ treatment were randomly taken from the middle portion $\left(6^{\text {th }}\right.$ and $7^{\text {th }}$ leaves) of current year's growth of selected shoots to determined leaf blade area according to following equation according to Ahmed and Morsy (1999) and cited after Shaheen et al. (2011)

Leaf area $=0.53$ (leaf length $\times$ leaf width $)+1.66$

\section{Flowering and fruit setting}

\subsection{Number of inflorescences per shoot:}

Average number of inflorescences per shoots was calculated for the selected shoots for each replicated tree.

\subsection{Number of perfect flowers per inflorescence:}

Twenty inflorescences at the middle portion of the select shoots were randomly selected from inner and outer portion of the tree canopy to determine the number of perfect flowers per inflorescence.

\subsection{Sex expression:}

Sex expression calculated according the next equation

$$
\text { Sex expression }=\frac{\text { no. of perfect flowers }}{\text { total no. of flowers }} \times 100
$$

\subsection{Initial fruit set}

Initial fruit set was calculated after twenty days of pollination according the next equation.

$$
\text { Initial fruit set }=\frac{\text { no. of initial fruit }}{\text { no. of perfect flowers }} \times 100
$$

\subsection{Horticulture fruit set}

Number of retained fruits of normal size at harvest was determined and horticulture fruit set was calculated according the next equation.

$$
\text { Horticulture fruit set }=\frac{\text { No. of Fruit at harvest }}{\text { No. of initial fruit }} \times 100
$$

\section{- Statistical analysis}

Results of this study were exposed to proper statistical analysis of variance for a split plot design with two factors "irrigation treatments were allocated as main plot and spraying dolomite nano-particles as sub plot" using statistix computer program (Anonymous, 2008) with three replicates. Each replicate's value was the average of two trees values. Duncan's multiple range tests were used to compare between means. Alphabetical letters in the column are significantly different at (0.05) level (Duncan, 1955). The same trees were used throughout both of experimental seasons.

\section{Results}

\section{Vegetative growth}

\subsection{Shoot length}

Results in table (6) exhibit that, spraying dolomite nano-particles at $6 \& 2 \mathrm{~g} / \mathrm{L}$ enhanced shoot length values $(17.0 \& 16.7 \mathrm{~cm})$ compared with other treatments in the first and the second seasons, respectively. Furthermore, 100\% of ETc irrigation level achieved the highest significant values of shoot length $(21.3 \& 20.0 \mathrm{~cm})$ compared with other treatments in the first and the second seasons, respectively.

1.2 Regarding the interaction between spraying dolomite nano-particles and irrigation levels, it's quite clear that Spraying dolomite nanoparticles at 6 and $2 \mathrm{~g} / \mathrm{L}$ and irrigation at $100 \%$ of ETc had the maximum values of shoot length $(24.7 \& 22.9 \mathrm{~cm})$ compared with other treatments in the first and the second seasons, respectively .

\section{Shoots number/ meter}

Table (7) clears that, spraying dolomite nanoparticles at $6 \mathrm{~g} / \mathrm{L}$ optimized shoots number/ meter (27.7 \& 33.5) compared with other treatments in the first and the second seasons, respectively. Likewise, $100 \%$ of ETc irrigation level achieved the highest significant values of shoots number/ meter (25.3 \& 33.6) compared with other treatments in the first and the second seasons, respectively.

Concerning the interaction between spraying dolomite nano-particles and irrigation levels, it's quite clear that spraying dolomite nano-particles at $6 \mathrm{~g} / \mathrm{L}$ and irrigation at $100 \%$ of ETc maximized shoots number/ meter (30.7 \& 41.3) compared with other treatments in the first and the second seasons, respectively. 
Table 6. Effect of irrigation and spraying dolomite nano-particles levels on shoot length of Picual olives during 2017 and 2018 seasons.

\begin{tabular}{|c|c|c|c|c|c|c|c|c|c|c|c|}
\hline \multicolumn{2}{|c|}{ parameter } & \multicolumn{10}{|c|}{ Shoot length $(\mathrm{cm})$} \\
\hline & & & & 2017 & & & & & 2018 & & \\
\hline \multicolumn{2}{|c|}{ Treatments } & \multicolumn{4}{|c|}{ Dolomite rate } & \multirow{2}{*}{$\begin{array}{c}\text { Irrigation } \\
\text { Mean }\end{array}$} & \multicolumn{4}{|c|}{ Dolomite rate } & \multirow{2}{*}{$\begin{array}{l}\text { Irrigation } \\
\text { Mean }\end{array}$} \\
\hline & & $0 \mathrm{~g} / \mathrm{L}$ & $2 \mathrm{~g} / \mathrm{L}$ & $4 \mathrm{~g} / \mathrm{L}$ & $6 \mathrm{~g} / \mathrm{L}$ & & $0 \mathrm{~g} / \mathrm{L}$ & $2 \mathrm{~g} / \mathrm{L}$ & $4 \mathrm{~g} / \mathrm{L}$ & $6 \mathrm{~g} / \mathrm{L}$ & \\
\hline \multirow{6}{*}{ 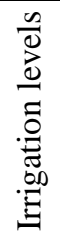 } & \multirow{2}{*}{$100 \%$} & 18.7 & 20.3 & 21.5 & 24.7 & 21.3 & 20.7 & 22.9 & 17.3 & 18.9 & 20.0 \\
\hline & & $\mathrm{d}$ & $\mathrm{bc}$ & $\mathrm{c}$ & $\mathrm{a}$ & A & $\mathrm{b}$ & $\mathrm{a}$ & $\mathrm{cd}$ & $\mathrm{c}$ & $\mathrm{A}$ \\
\hline & \multirow{2}{*}{$75 \%$} & 13.2 & 16.5 & 16.9 & 18.2 & 16.2 & 13.7 & 17.9 & 16.4 & 13.5 & 15.4 \\
\hline & & $\mathrm{e}$ & $\mathrm{d}$ & $\mathrm{d}$ & $\mathrm{d}$ & B & $\mathrm{cd}$ & $\mathrm{d}$ & $\mathrm{e}$ & $\mathrm{e}$ & B \\
\hline & \multirow{2}{*}{$50 \%$} & 4.8 & 6.2 & 7.5 & 8.1 & 6.6 & 6.7 & 9.2 & 8.6 & 8.0 & 8.1 \\
\hline & & $\mathrm{g}$ & fg & $\mathrm{f}$ & $\mathrm{f}$ & $\mathrm{C}$ & $\mathrm{g}$ & $\mathrm{f}$ & $\mathrm{f}$ & fg & $\mathrm{C}$ \\
\hline \multirow{2}{*}{\multicolumn{2}{|c|}{ Dolomite Mean }} & 12.2 & 14.4 & 15.3 & 17.0 & & 13.7 & 16.7 & 14.1 & 13.5 & \\
\hline & & $\mathrm{C}$ & $\mathrm{B}$ & $\mathrm{B}$ & A & & $\mathrm{B}$ & A & $\mathrm{B}$ & $\mathrm{B}$ & \\
\hline
\end{tabular}

Table 7. Effect of irrigation and spraying dolomite nano-particles levels on shoots number /meter of Picual olives during 2017 and 2018 seasons.

\begin{tabular}{|c|c|c|c|c|c|c|c|c|c|c|c|}
\hline \multicolumn{2}{|c|}{ parameter } & \multicolumn{10}{|c|}{ Shoot number/meter } \\
\hline \multirow{3}{*}{\multicolumn{2}{|c|}{ Treatments }} & \multicolumn{5}{|c|}{2017} & \multicolumn{5}{|c|}{2018} \\
\hline & & \multicolumn{4}{|c|}{ Dolomite rate } & \multirow{2}{*}{$\begin{array}{l}\text { Irrigation } \\
\text { Mean }\end{array}$} & \multicolumn{4}{|c|}{ Dolomite rate } & \multirow{2}{*}{$\begin{array}{c}\text { Irrigation } \\
\text { Mean }\end{array}$} \\
\hline & & $0 \mathrm{~g} / \mathrm{L}$ & $2 \mathrm{~g} / \mathrm{L}$ & $4 \mathrm{~g} / \mathrm{L}$ & $6 \mathrm{~g} / \mathrm{L}$ & & $0 \mathrm{~g} / \mathrm{L}$ & $2 \mathrm{~g} / \mathrm{L}$ & $4 \mathrm{~g} / \mathrm{L}$ & $6 \mathrm{~g} / \mathrm{L}$ & \\
\hline \multirow{6}{*}{ 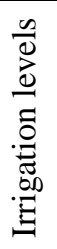 } & \multirow{2}{*}{$100 \%$} & 18.7 & 24.0 & 28.0 & 30.7 & 25.3 & 27.7 & 30.6 & 34.7 & 41.3 & 33.6 \\
\hline & & $\mathrm{d}$ & c & $\mathrm{b}$ & $\mathrm{a}$ & A & de & $\mathrm{c}$ & $\mathrm{b}$ & $\mathrm{a}$ & A \\
\hline & \multirow{2}{*}{$75 \%$} & 14.0 & 19.0 & 23.3 & 27.7 & 21.0 & 25.3 & 26.3 & 28.0 & 30.3 & 27.5 \\
\hline & & $\mathrm{e}$ & $\mathrm{d}$ & $\mathrm{c}$ & $\mathrm{bc}$ & B & $\mathrm{f}$ & ef & de & $\mathrm{c}$ & B \\
\hline & \multirow{2}{*}{$50 \%$} & 14.2 & 13.5 & 18.6 & 24.6 & 17.8 & 19.1 & 23.3 & 25.3 & 28.9 & 24.2 \\
\hline & & $\mathrm{e}$ & $\mathrm{e}$ & $\mathrm{d}$ & $\mathrm{c}$ & $\mathrm{C}$ & $\mathrm{h}$ & $\mathrm{g}$ & $\mathrm{f}$ & $\mathrm{cd}$ & $\mathrm{C}$ \\
\hline \multirow{2}{*}{\multicolumn{2}{|c|}{ Dolomite Mean }} & 15.6 & 18.8 & 23.3 & 27.7 & & 24.00 & 26.7 & 29.3 & 33.5 & \\
\hline & & $\mathrm{D}$ & $\mathrm{C}$ & B & A & & D & $\mathrm{C}$ & B & A & \\
\hline
\end{tabular}

\subsection{Leaf area $\left(\mathrm{cm}^{2}\right)$}

Table (8) illustrates that, spraying dolomite nanoparticles at $6 \mathrm{~g} / \mathrm{L}$ concentration increased leaf area values $\left(4.36 \& 5.62 \mathrm{~cm}^{2}\right)$ compared with other treatments in the first and the second seasons, respectively. Besides, irrigation at $100 \%$ of ETc gave highest leaf area values $\left(4.29 \& 5.91 \mathrm{~cm}^{2}\right)$ with nonsignificance between it and $75 \%$ of ETc in the first season compared with other treatments in the first and the second seasons, respectively.

Concerning interaction, it's clear that spraying dolomite nano-particles at $6 \mathrm{~g} / \mathrm{L}$ concentration and irrigation at $100 \%$ of ETc had maximum leaf area values $\left(4.82 \& 6.80 \mathrm{~cm}^{2}\right)$ with non-significance between it and spraying $4 \mathrm{~g} / \mathrm{L}$ with irrigation at $100 \%$ of ETc in first season compared with other treatments in the first and the second seasons, respectively.

Table 8. Effect of irrigation and spraying dolomite nano-particles levels on Leaf area of Picual olives during 2017 and 2018 seasons.

\begin{tabular}{|c|c|c|c|c|c|c|c|c|c|c|c|}
\hline \multicolumn{2}{|c|}{ Parameter } & \multicolumn{10}{|c|}{ Leaf area $\left(\mathrm{cm}^{2}\right)$} \\
\hline \multirow{3}{*}{\multicolumn{2}{|c|}{ Treatments }} & \multicolumn{5}{|c|}{2017} & \multicolumn{5}{|c|}{2018} \\
\hline & & \multicolumn{4}{|c|}{ Dolomite rate } & \multirow{2}{*}{$\begin{array}{c}\text { Irrigation } \\
\text { Mean }\end{array}$} & \multicolumn{4}{|c|}{ Dolomite rate } & \multirow{2}{*}{$\begin{array}{c}\text { Irrigation } \\
\text { Mean }\end{array}$} \\
\hline & & $0 \mathrm{~g} / \mathrm{L}$ & $2 \mathrm{~g} / \mathrm{L}$ & $4 \mathrm{~g} / \mathrm{L}$ & $6 \mathrm{~g} / \mathrm{L}$ & & $0 \mathrm{~g} / \mathrm{L}$ & $2 \mathrm{~g} / \mathrm{L}$ & $4 \mathrm{~g} / \mathrm{L}$ & $6 \mathrm{~g} / \mathrm{L}$ & \\
\hline \multirow{6}{*}{ 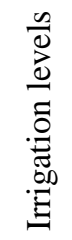 } & \multirow{2}{*}{$100 \%$} & 3.58 & 4.06 & 4.71 & 4.82 & 4.29 & 5.00 & 5.75 & 6.09 & 6.80 & 5.91 \\
\hline & & $\mathrm{cd}$ & $\mathrm{b}$ & $\mathrm{a}$ & $\mathrm{a}$ & A & de & $\mathrm{bc}$ & $\mathrm{b}$ & $\mathrm{a}$ & A \\
\hline & \multirow{2}{*}{$75 \%$} & 3.74 & 3.99 & 4.20 & 4.60 & 4.13 & 3.76 & 4.51 & 5.46 & 5.75 & 4.87 \\
\hline & & $\mathrm{c}$ & $\mathrm{b}$ & $\mathrm{b}$ & $\mathrm{a}$ & A & $\mathrm{g}$ & ef & $\mathrm{cd}$ & $\mathrm{bc}$ & $\mathrm{B}$ \\
\hline & \multirow{2}{*}{$50 \%$} & 3.36 & 3.55 & 3.55 & 3.66 & 3.53 & 3.24 & 3.76 & 4.24 & 4.32 & 3.89 \\
\hline & & $\mathrm{d}$ & $\mathrm{cd}$ & $\mathrm{cd}$ & $\mathrm{c}$ & $\mathrm{B}$ & $\mathrm{h}$ & $\mathrm{g}$ & $\mathrm{fg}$ & $\mathrm{f}$ & $\mathrm{C}$ \\
\hline \multirow{2}{*}{\multicolumn{2}{|c|}{ Dolomite Mean }} & 3.56 & 3.87 & 4.16 & 4.36 & & 4.00 & 4.67 & 5.26 & 5.62 & \\
\hline & & $\mathrm{D}$ & $\mathrm{C}$ & $\mathrm{B}$ & A & & $\mathrm{D}$ & $\mathrm{C}$ & $\mathrm{B}$ & A & \\
\hline
\end{tabular}

\section{Flowering and fruit setting}

\subsection{Inflorescences number/ shoot}

As shown in table (9), spraying with dolomite nano-particles at $2 \mathrm{~g} / \mathrm{L}$ gave the highest values of inflorescences number/ shoot (6.08 \& 4.21) compared with other treatments in the first and the second seasons, respectively with non-significance between it and $4 \mathrm{~g} / \mathrm{L}$ in second season only. Moreover, irrigation 
at $75 \%$ of ETc significantly increased inflorescences number/ shoot (5.58 \& 4.36) compared with other treatments in the first and the second seasons, respectively.

The interaction between irrigation levels and dolomite nano-particles showed that the highest values of inflorescences number/ shoot were noticed with $75 \%$ of ETc irrigation level and spraying dolomite nano-particles at $2 \mathrm{~g} / \mathrm{L}(7.53 \quad \& \quad 6.53)$ compared with other treatments in the first and the second seasons, respectively with non-significant between it and $4 \mathrm{~g} / \mathrm{L}$ spraying level and $75 \%$ irrigation level in second seasons.

Table 9. Effect of irrigation and spraying dolomite nano-particles levels on inflorescence number / shoot of Picual olives during 2017 and 2018 seasons.

\begin{tabular}{|c|c|c|c|c|c|c|c|c|c|c|c|}
\hline \multicolumn{2}{|c|}{ parameter } & \multicolumn{10}{|c|}{ Inflorescence number per shoot } \\
\hline \multirow{3}{*}{\multicolumn{2}{|c|}{ Treatments }} & \multicolumn{5}{|c|}{2017} & \multicolumn{5}{|c|}{2018} \\
\hline & & \multicolumn{4}{|c|}{ Dolomite rate } & \multirow{2}{*}{$\begin{array}{l}\text { Irrigation } \\
\text { Mean }\end{array}$} & \multicolumn{4}{|c|}{ Dolomite rate } & \multirow{2}{*}{$\begin{array}{c}\text { Irrigation } \\
\text { Mean }\end{array}$} \\
\hline & & $0 \mathrm{~g} / \mathrm{L}$ & $2 \mathrm{~g} / \mathrm{L}$ & $4 \mathrm{~g} / \mathrm{L}$ & $6 \mathrm{~g} / \mathrm{L}$ & & $0 \mathrm{~g} / \mathrm{L}$ & $2 \mathrm{~g} / \mathrm{L}$ & $4 \mathrm{~g} / \mathrm{L}$ & $6 \mathrm{~g} / \mathrm{L}$ & \\
\hline \multirow{6}{*}{ 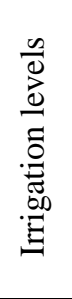 } & \multirow{2}{*}{$100 \%$} & 3.23 & 5.18 & 4.41 & 4.23 & 4.26 & 4.49 & 4.07 & 3.79 & 2.97 & 3.33 \\
\hline & & $\mathrm{e}$ & $\mathrm{c}$ & $\mathrm{d}$ & $\mathrm{d}$ & $\mathrm{B}$ & $\mathrm{cd}$ & $\mathrm{bc}$ & $\mathrm{b}$ & $\mathrm{c}$ & $\mathrm{B}$ \\
\hline & \multirow{2}{*}{$75 \%$} & 3.97 & 7.53 & 6.77 & 4.07 & 5.58 & 2.38 & 6.53 & 6.27 & 2.27 & 4.36 \\
\hline & & $\mathrm{d}$ & $\mathrm{a}$ & $\mathrm{b}$ & $\mathrm{d}$ & A & de & $\mathrm{a}$ & $\mathrm{a}$ & $d-f$ & $\mathrm{~A}$ \\
\hline & \multirow{2}{*}{$50 \%$} & 2.21 & 5.53 & 2.60 & 2.37 & 3.18 & 1.27 & 2.04 & 1.88 & 1.81 & 1.75 \\
\hline & & $\mathrm{g}$ & $\mathrm{c}$ & $\mathrm{f}$ & $\mathrm{fg}$ & $\mathrm{C}$ & $\mathrm{g}$ & def & ef & $\mathrm{fg}$ & $\mathrm{C}$ \\
\hline \multirow{2}{*}{\multicolumn{2}{|c|}{ Dolomite Mean }} & 3.14 & 6.08 & 4.59 & 3.55 & & 2.05 & 4.21 & 3.98 & 2.35 & \\
\hline & & $\mathrm{D}$ & A & B & $\mathrm{C}$ & & B & A & A & $\mathrm{B}$ & \\
\hline
\end{tabular}

\subsection{Perfect flowers}

Table (10) shows that spraying dolomite nanoparticles at $2 \mathrm{~g} / \mathrm{L}$ gave the highest values of perfect flowers (11.92 \& 7.86) compared with other treatments in the first and the second seasons, respectively. Also, $75 \%$ of ETc significantly had the greatest value of perfect flowers (11.24 \& 6.73) with non-significance between it and $100 \%$ of ETc (11.14 $\& 6.71$ ) compared with $50 \%$ of ETc in the first and the second seasons.
The interaction between irrigation levels and spraying dolomite nano-particles showed that the highest values of perfect flowers were noticed with spraying dolomite nano-particles at $2 \mathrm{~g} / \mathrm{L}$ and $100 \%$ of ETc irrigation level (14.16 \& 8.71) followed by spraying at $2 \mathrm{~g} / \mathrm{L}$ and $75 \%$ of ETc irrigation level (13.20 \& 8.60) compared with $50 \%$ of ETc irrigation level in the first and the second seasons, respectively.

Table 10. Effect of irrigation and spraying dolomite nano-particles levels on Perfect flowers of Picual olives during 2017 and 2018 seasons.

\begin{tabular}{|c|c|c|c|c|c|c|c|c|c|c|c|}
\hline \multicolumn{2}{|c|}{ parameter } & \multicolumn{10}{|c|}{ number of Perfect flowers / inflorescences } \\
\hline \multirow{3}{*}{\multicolumn{2}{|c|}{ Treatments }} & \multicolumn{5}{|c|}{2017} & \multicolumn{5}{|c|}{2018} \\
\hline & & \multicolumn{4}{|c|}{ Dolomite rate } & \multirow{2}{*}{$\begin{array}{l}\text { Irrigation } \\
\text { Mean }\end{array}$} & \multicolumn{4}{|c|}{ Dolomite rate } & \multirow{2}{*}{$\begin{array}{c}\text { Irrigation } \\
\text { Mean }\end{array}$} \\
\hline & & $0 \mathrm{~g} / \mathrm{L}$ & $2 \mathrm{~g} / \mathrm{L}$ & $4 \mathrm{~g} / \mathrm{L}$ & $6 \mathrm{~g} / \mathrm{L}$ & & $0 \mathrm{~g} / \mathrm{L}$ & $2 \mathrm{~g} / \mathrm{L}$ & $4 \mathrm{~g} / \mathrm{L}$ & $6 \mathrm{~g} / \mathrm{L}$ & \\
\hline \multirow{6}{*}{ 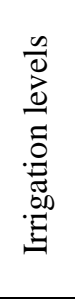 } & \multirow{2}{*}{$100 \%$} & 9.20 & 14.16 & 13.30 & 7.90 & 11.14 & 5.34 & 8.71 & 8.01 & 4.80 & 6.71 \\
\hline & & $\mathrm{c}$ & $\mathrm{a}$ & $\mathrm{ab}$ & $\mathrm{cd}$ & A & $\mathrm{cd}$ & $\mathrm{a}$ & $\mathrm{a}$ & Cde & A \\
\hline & \multirow{2}{*}{$75 \%$} & 8.43 & 13.20 & 11.80 & 11.53 & 11.24 & 4.61 & 8.60 & 8.05 & 5.64 & 6.73 \\
\hline & & $\mathrm{cd}$ & $a b$ & $\mathrm{~b}$ & $\mathrm{~b}$ & A & de & $\mathrm{a}$ & $\mathrm{a}$ & $\mathrm{Bc}$ & A \\
\hline & \multirow{2}{*}{$50 \%$} & 7.73 & 8.40 & 7.01 & 6.33 & 6.62 & 3.04 & 6.27 & 5.67 & 4.21 & 4.80 \\
\hline & & ef & $\mathrm{cd}$ & $\mathrm{cd}$ & de & $\mathrm{B}$ & $\mathrm{f}$ & $\mathrm{b}$ & $\mathrm{bc}$ & $\mathrm{E}$ & $\mathrm{B}$ \\
\hline \multirow{2}{*}{\multicolumn{2}{|c|}{ Dolomite Mean }} & 7.46 & 11.92 & 10.70 & 8.59 & & 4.33 & 7.86 & 7.25 & 4.89 & \\
\hline & & $\mathrm{D}$ & A & $\mathrm{B}$ & $\mathrm{C}$ & & $\mathrm{D}$ & $\mathrm{A}$ & $\mathrm{B}$ & $\mathrm{C}$ & \\
\hline
\end{tabular}

\subsection{Sex expression}

Data presented in table (11) indicate that spraying dolomite nano-particles at $4 \mathrm{~g} / \mathrm{L}$ gave the highest significant values of sex expression $(71.63 \& 70.13$
$\%)$ with non-significance between it and $2 \mathrm{~g} / \mathrm{L}$ (71.10 \& $69.70 \%$ ) compared with other treatments in the first and the second seasons, respectively. Besides, the highest significant value of sex expression was gained 
by $100 \%$ of ETc irrigation level in the first season (77.05) and $75 \%$ of ETc in the second season (67.24).

Concerning the interaction, it's obvious that trees which received $4 \mathrm{~g} / \mathrm{L}$ of dolomite nano-particles and
$100 \%$ of ETc irrigation have the highest significant sex expression (88.31 \& $78.78 \%$ ) compared with other treatments in the first and the second seasons, respectively.

Table 11. Effect of irrigation and spraying dolomite nano-particles levels on sex expression of Picual olives during 2017 and 2018 seasons.

\begin{tabular}{|c|c|c|c|c|c|c|c|c|c|c|c|}
\hline \multicolumn{2}{|c|}{ parameter } & \multicolumn{10}{|c|}{ Sex expression $(\%)$} \\
\hline \multirow{3}{*}{\multicolumn{2}{|c|}{ Treatments }} & \multicolumn{5}{|c|}{2017} & \multicolumn{5}{|c|}{2018} \\
\hline & & \multicolumn{4}{|c|}{ Dolomite rate } & \multirow{2}{*}{$\begin{array}{c}\text { Irrigation } \\
\text { Mean }\end{array}$} & \multicolumn{4}{|c|}{ Dolomite rate } & \multirow{2}{*}{$\begin{array}{c}\text { Irrigation } \\
\text { Mean }\end{array}$} \\
\hline & & $0 \mathrm{~g} / \mathrm{L}$ & $2 \mathrm{~g} / \mathrm{L}$ & $4 \mathrm{~g} / \mathrm{L}$ & $6 \mathrm{~g} / \mathrm{L}$ & & $0 \mathrm{~g} / \mathrm{L}$ & $2 \mathrm{~g} / \mathrm{L}$ & $4 \mathrm{~g} / \mathrm{L}$ & $6 \mathrm{~g} / \mathrm{L}$ & \\
\hline \multirow{6}{*}{ 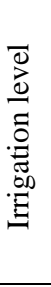 } & \multirow{2}{*}{$100 \%$} & 77.27 & 86.07 & 88.31 & 56.49 & 77.05 & 58.21 & 71.93 & 78.78 & 51.89 & 65.20 \\
\hline & & $\mathrm{b}$ & a & $\mathrm{a}$ & de & A & $\mathrm{f}$ & $\mathrm{c}$ & $\mathrm{a}$ & $\mathrm{g}$ & B \\
\hline & \multirow{2}{*}{$75 \%$} & 56.96 & 62.84 & 62.11 & 68.07 & 62.49 & 53.53 & 75.41 & 68.62 & 71.41 & 67.24 \\
\hline & & de & $\mathrm{cd}$ & c-e & $\mathrm{bc}$ & B & $\mathrm{g}$ & $\mathrm{b}$ & $\mathrm{d}$ & $\mathrm{c}$ & A \\
\hline & \multirow{2}{*}{$50 \%$} & 42.21 & 64.32 & 64.46 & 52.75 & 55.94 & 41.52 & 61.75 & 63.07 & 53.34 & 54.90 \\
\hline & & $\mathrm{f}$ & $\mathrm{cd}$ & $\mathrm{e}$ & de & $\mathrm{C}$ & $\mathrm{h}$ & $\mathrm{e}$ & $\mathrm{e}$ & $\mathrm{g}$ & $\mathrm{C}$ \\
\hline \multirow{2}{*}{\multicolumn{2}{|c|}{ Dolomite Mean }} & 58.81 & 71.10 & 71.63 & 59.10 & & 51.08 & 69.70 & 70.13 & 58.88 & \\
\hline & & B & A & A & B & & $\mathrm{C}$ & A & A & B & \\
\hline
\end{tabular}

\subsection{Initial fruit set}

Table (12) indicates that spraying dolomite nanoparticles at $2 \mathrm{~g} / \mathrm{L}$ had the highest significant values of initial fruit set $(3.32 \& 3.63 \%)$ compared with other treatments in the first and the second seasons, respectively with non-significance between them and $4 \mathrm{~g} / \mathrm{L}$ in the first seasons only. Moreover, irrigation at $75 \%$ of ETc significantly increased initial fruit set
(3.82 \& $3.51 \%)$ compared with other irrigation levels in the first and the second seasons, respectively.

Regarding the interaction, it's obvious that trees which received $2 \mathrm{~g} / \mathrm{L}$ of dolomite nano-particles and $75 \%$ of ETc irrigation level have the highest significant values of initial fruit set (4.28 \& $4.53 \%)$ compared with other treatments in the first and the second seasons, respectively.

Table 12 . Effect of irrigation and spraying dolomite nano-particles levels on initial fruit set of Picual olives during 2017 and 2018 seasons.

\begin{tabular}{|c|c|c|c|c|c|c|c|c|c|c|c|}
\hline \multicolumn{2}{|c|}{ parameter } & \multicolumn{10}{|c|}{ Initial fruit set (\%) } \\
\hline \multirow{3}{*}{\multicolumn{2}{|c|}{ Treatment }} & \multicolumn{5}{|c|}{2017} & \multicolumn{5}{|c|}{2018} \\
\hline & & \multicolumn{4}{|c|}{ Dolomite rate } & \multirow{2}{*}{$\begin{array}{c}\text { Irrigatio } \\
\mathrm{n} \\
\text { Mean }\end{array}$} & \multicolumn{4}{|c|}{ Dolomite rate } & \multirow{2}{*}{$\begin{array}{c}\text { Irrigatio } \\
\mathrm{n} \\
\text { Mean }\end{array}$} \\
\hline & & $\begin{array}{c}0 \mathrm{~g} / \\
\mathrm{L}\end{array}$ & $\begin{array}{c}2 \mathrm{~g} / \\
\mathrm{L}\end{array}$ & $\begin{array}{c}4 \mathrm{~g} / \\
\mathrm{L} \\
\end{array}$ & $\begin{array}{c}6 \mathrm{~g} / \\
\mathrm{L} \\
\end{array}$ & & $\begin{array}{c}0 \mathrm{~g} / \\
\mathrm{L}\end{array}$ & $\begin{array}{c}2 \mathrm{~g} / \\
\mathrm{L}\end{array}$ & $\begin{array}{c}4 \mathrm{~g} / \\
\mathrm{L} \\
\end{array}$ & $\begin{array}{c}6 \mathrm{~g} / \\
\mathrm{L}\end{array}$ & \\
\hline \multirow{3}{*}{ 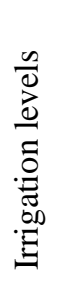 } & $100 \%$ & $\begin{array}{c}2.89 \\
\mathrm{~cd}\end{array}$ & $\begin{array}{c}3.21 \\
\mathrm{bc}\end{array}$ & $\begin{array}{c}3.78 \\
a b\end{array}$ & $\begin{array}{c}2.47 \\
\mathrm{~d}\end{array}$ & $\begin{array}{c}3.09 \\
\text { B }\end{array}$ & $\begin{array}{c}1.23 \\
\mathrm{gh}\end{array}$ & $\begin{array}{c}3.92 \\
b\end{array}$ & $\begin{array}{c}3.17 \\
\mathrm{c}\end{array}$ & $\begin{array}{c}1.27 \\
\mathrm{~g}\end{array}$ & $\begin{array}{c}2.40 \\
\text { B }\end{array}$ \\
\hline & $75 \%$ & $\begin{array}{c}2.76 \\
\mathrm{~cd}\end{array}$ & $\begin{array}{c}4.28 \\
\mathrm{a}\end{array}$ & $\begin{array}{c}4.17 \\
\mathrm{a}\end{array}$ & $\begin{array}{c}4.06 \\
\mathrm{a}\end{array}$ & $\begin{array}{c}3.82 \\
\mathrm{~A}\end{array}$ & $\begin{array}{c}2.82 \\
\mathrm{~d}\end{array}$ & $\begin{array}{c}4.53 \\
\mathrm{a}\end{array}$ & $\begin{array}{c}4.30 \\
\mathrm{a}\end{array}$ & $\begin{array}{c}2.37 \\
\mathrm{e}\end{array}$ & $\begin{array}{c}3.51 \\
\mathrm{~A}\end{array}$ \\
\hline & $50 \%$ & $\begin{array}{c}1.31 \\
\text { ef }\end{array}$ & $\begin{array}{c}2.47 \\
\mathrm{~d} \\
\end{array}$ & $\begin{array}{c}1.81 \\
\mathrm{e} \\
\end{array}$ & $\begin{array}{c}1.04 \\
\mathrm{f} \\
\end{array}$ & $\begin{array}{c}1.66 \\
\mathrm{C} \\
\end{array}$ & $\begin{array}{c}1.12 \\
\mathrm{gh}\end{array}$ & $\begin{array}{c}2.42 \\
\mathrm{e} \\
\end{array}$ & $\begin{array}{c}1.93 \\
\mathrm{f} \\
\end{array}$ & $\begin{array}{c}0.92 \\
\mathrm{~h} \\
\end{array}$ & $\begin{array}{c}1.60 \\
\mathrm{C} \\
\end{array}$ \\
\hline \multicolumn{2}{|c|}{$\begin{array}{l}\text { Dolomite } \\
\text { Mean }\end{array}$} & $\begin{array}{c}2.32 \\
\mathrm{~B} \\
\end{array}$ & $\begin{array}{c}3.32 \\
\mathrm{~A}\end{array}$ & $\begin{array}{c}3.21 \\
\mathrm{~A} \\
\end{array}$ & $\begin{array}{c}2.56 \\
\mathrm{~B} \\
\end{array}$ & & $\begin{array}{c}1.72 \\
\mathrm{C}\end{array}$ & $\begin{array}{c}3.63 \\
\mathrm{~A} \\
\end{array}$ & $\begin{array}{c}3.13 \\
\mathrm{~B}\end{array}$ & $\begin{array}{c}1.52 \\
\mathrm{D} \\
\end{array}$ & \\
\hline
\end{tabular}

\subsection{Horticulture fruit set}

Presented data in table (13) clraify that spraying dolomite nano-particles at $4 \& 2 \mathrm{~g} / \mathrm{L}$ concentrarions recorded the highest values of horticulture fruit set (55.68 \& $65.98 \%)$ with non-significance between it and $0 \& 4 \mathrm{~g} / \mathrm{L}$ in first season compared with other treatments in the first and the second seasons, respectively. In addition, irrigation at $75 \%$ of ETc recorded the highest values of horticulture fruit set
$(67.05 \& 73.02 \%)$ compared with other treatments in the first and the second seasons, respectively.

Regarding the interaction between irrigation and spraying dolomite nano-particles the highest values of horticulture fruit set were recorded with spraying dolomite nano-particles at $2 \mathrm{~g} / \mathrm{L}$ and irrigation at $75 \%$ of ETc $(71.33 \& 77.50 \%)$ compared with other treatments in the first and the second seasons, respectively. 
Table 13. Effect of irrigation and spraying dolomite nano-particles levels on horticulture fruit set of Picual olives during 2017 and 2018 seasons.

\begin{tabular}{|c|c|c|c|c|c|c|c|c|c|c|c|}
\hline \multicolumn{2}{|c|}{ parameter } & \multicolumn{10}{|c|}{ Horticulture fruit set $(\%)$} \\
\hline \multirow{3}{*}{\multicolumn{2}{|c|}{ Treatment }} & \multicolumn{5}{|c|}{2017} & \multicolumn{5}{|c|}{2018} \\
\hline & & & \multicolumn{2}{|c|}{ Dolomite rate } & & \multirow{2}{*}{$\begin{array}{c}\text { Irrigation } \\
\text { Mean }\end{array}$} & \multicolumn{4}{|c|}{ Dolomite rate } & \multirow{2}{*}{$\begin{array}{l}\text { Irrigation } \\
\text { Mean }\end{array}$} \\
\hline & & & $2 \mathrm{~g} / \mathrm{L}$ & $4 \mathrm{~g} / \mathrm{L}$ & $6 \mathrm{~g} / \mathrm{L}$ & & $0 \mathrm{~g} / \mathrm{L}$ & $2 \mathrm{~g} / \mathrm{L}$ & $4 \mathrm{~g} / \mathrm{L}$ & $6 \mathrm{~g} / \mathrm{L}$ & \\
\hline$\frac{\infty}{2}$ & $100 \%$ & $\begin{array}{c}46.67 \\
\mathrm{~g}\end{array}$ & $\begin{array}{c}47.99 \\
\text { fg }\end{array}$ & $\begin{array}{c}49.66 \\
\mathrm{e}\end{array}$ & $\begin{array}{c}50.33 \\
\mathrm{e}\end{array}$ & $\begin{array}{c}48.66 \\
\text { B }\end{array}$ & $\begin{array}{c}61.83 \\
\text { ef }\end{array}$ & $\begin{array}{c}64.30 \\
\mathrm{de}\end{array}$ & $\begin{array}{c}63.80 \\
\text { de }\end{array}$ & $\begin{array}{c}65.63 \\
d\end{array}$ & $\begin{array}{c}63.89 \\
\text { B }\end{array}$ \\
\hline శี & $75 \%$ & $\begin{array}{c}63.86 \\
c\end{array}$ & $\begin{array}{c}71.33 \\
\mathrm{a}\end{array}$ & $\begin{array}{c}68.66 \\
b\end{array}$ & $\begin{array}{c}64.32 \\
c\end{array}$ & $\begin{array}{c}67.05 \\
\text { A }\end{array}$ & $\begin{array}{c}72.33 \\
b\end{array}$ & $\begin{array}{c}77.50 \\
\mathrm{a}\end{array}$ & $\begin{array}{c}73.50 \\
b\end{array}$ & $\begin{array}{c}68.73 \\
c\end{array}$ & $\begin{array}{c}73.02 \\
\mathrm{~A}\end{array}$ \\
\hline$\cdot{ }^{500}$ & $50 \%$ & $\begin{array}{c}55.15 \\
\mathrm{~d}\end{array}$ & $\begin{array}{c}47.55 \\
\mathrm{fg}\end{array}$ & $\begin{array}{c}48.72 \\
\text { ef }\end{array}$ & $\begin{array}{c}43.43 \\
h\end{array}$ & $\begin{array}{c}48.71 \\
\text { B }\end{array}$ & $\begin{array}{c}55.67 \\
\mathrm{f}\end{array}$ & $\begin{array}{c}56.13 \\
\mathrm{f}\end{array}$ & $\begin{array}{c}51.52 \\
\mathrm{~g}\end{array}$ & $\begin{array}{c}48.83 \\
\mathrm{~g}\end{array}$ & $\begin{array}{c}53.04 \\
\mathrm{C}\end{array}$ \\
\hline \multirow{2}{*}{\multicolumn{2}{|c|}{ Dolomite Mean }} & 55.22 & 55.62 & 55.68 & 52.70 & & 63.28 & 65.98 & 62.94 & 61.07 & \\
\hline & & A & $\mathrm{A}$ & A & B & & B & A & $\mathrm{B}$ & $\mathrm{C}$ & \\
\hline
\end{tabular}

\section{Discussion}

Results show that growing seasons affected on olive growth, blooming and fruit setting due to alternative bearing. Values of shoot length, number of shoots, leaf area and horticultural fruit set in the second season were higher than those in first season and vice versa for perfect flowers, inflorescences no., sex expression and initial fruit set.

\section{Effect of irrigation levels on olive growth, flowering and fruit setting.}

Results indicate that water stress is a vital factor limiting olive cultivation in Mediterranean basin, also it can impair the performance of olives growth, flowering and fruit setting.

Concerning vegetative growth, applying irrigation at $100 \%$ of ETc stimulated vegetative growth and increased shoot length, shoots number in the first and the second seasons. Moreover, leaf area was increased in second season. Irrigation at $50 \%$ of ETc led to decrease shoot length, shoots number and leaf area in the both seasons. These results agree with Arzani and Arji, (2000), Guerfel et al. (2009) and Shaheen et al. (2011). The negative effect of prolonged water stress may lead to reduce the plant-cell's water potential and turgor pressure which affects the rate of cell expansion and ultimate cell size. Drought doesn't only affect physiological processes but also biochemical processes. Thus, drought stress caused reduction in vegetative growth parameters.

Blooming and fruit setting were affected by different irrigation levels. The most promising level "75\% of ETc" showed the highest values of perfect flowers, inflorescences no., initial fruit set and horticultural fruit set in the first and the second seasons in addition to sex expression in second season. While irrigation at $100 \%$ of ETc increased vegetative growth, which led to decrease blooming and fruit setting. Moreover, prolonged water stress " $50 \%$ of ETc" led to decrease vegetative, assimilation of the leaf so It impair blooming and fruit setting. These results are in harmony with Lavee and wonder (1992), Bignami et al. (1995), Wu-ShuBiao (2002), Vrhovnik (2004) and Rapoport et al. (2011)
Effect of spraying dolomite nano-particles on olives growth, flowering and fruit setting.

Concerning vegetative growth, results indicate that spraying dolomite nano-particles $(6 \mathrm{~g} / \mathrm{L})$ Stimulated vegetative growth and increased shoots number, leaves area in the first and the second seasons in addition to shoot length in the first season. These results agree with Abd El-Aal and Eid, (2018).

Regarding blooming, spraying dolomite nanoparticles $(2 \mathrm{~g} / \mathrm{L})$ gave the highest values of perfect flower, sex expression, initial fruit set and horticultural fruit set. These results agree with Abdelghafar et al. (2016).

These parameters could be improved because of enhancing physiological, biological, assimilation and dissimilation process, because of elevated $\mathrm{CO}_{2}$ in intercellular compartment and on leave surface which lead to close stomata, decrease transpiration rate and enhance photosynthesis in addition to water use efficiency according to Kumar et al. (2013). Also, spraying dolomite nano-particles may play an effective role because of its components (Abdel Nabi et al., 2017 and Ghatas et al., 2018). Physiological and chemical analysis will clarify the actual reason of these effects.

\section{Conclusions}

At the end of this research we recommend application of spraying dolomite nano-particles at 2 $\mathrm{g} / \mathrm{L}$ to increase perfect flowers, sex expression, initial fruit set and horticultural fruit set of Picual olive cv. Furthermore, irrigation at $75 \%$ of ETc were recommended to balance between vegetative, blooming and productivity. Moreover, it showed the highest significant values of perfect flowers, inflorescences no., initial fruit set and horticulture fruit set.

Concerning the inter action between irrigation and spraying dolomite nano-particles it could be concluded that perfect flowers, initial fruit ses and horticulture fruit set were improved and showed the highest walues by spraying dolomite nano-particles at $2 \mathrm{~g} / \mathrm{L}$ 


\section{Acknowledgement}

I find it is a golden moment to reiterate my indebtedness and deep sense of regards to Academic of scientific research and technology which funded this research. It was a part of master study in Pomology at Horticulture department, Faculty of agriculture, Benha University, Egypt.

All words would be futile, meaningless and flounders to articulate extreme sense of veneration to Dr. Sabry Osman, Professor of pomology at Plant production department, Desert research center for supporting me and providing the necessary research facilities.

\section{References}

Abdel Nabi, H.; K. Dawa; E. El-Gamily and Y. Imryed (2017). Effect of magnetic water, foliar application with nano material and nitrogen levels on productivity and quality of head lettuce. Int. J. Adv. Res. Biol. Sci., 4 (5):, 171-181.

Abdelal, M. and S. Eid (2018). Effect of foliar spray with Lithovit and amino acids on growth, bio constituents, anatomical and yield features of soybean plant. 4th International Conference on Biotechnology Applications in Agriculture (ICBAA), Benha University, Moshtohor and Hurghada, 4-7 April 2018, Egypt

Abdelghafar, M. S.; M. AlAbd; A. Helaly and A. Rashwan (2016). Foliar Application of Lithovit and Rose Water as Factor for Increasing Onion Seed Production. Nat. Sci., 14 (3), 53-61

Ahmed, F. and M. Morsy (1999). A new method for measuring leaf area in different fruit species. Minia J. of Agric Res. Develop, 19, 97-105.

Ainsworth, E. and A. Rogers (2007). The response of photosynthesis and stomatal conductance to rising [CO2]: mechanisms and environmental interactions J. Plant, Cell \& Environment. 30, 258-270.

Anonymous (2008). Statistix 9 User's Manual. Analytical Software, Tallahassee, FL. 454 p.

Arzani, K. and I. Arji (2000). The effect of water stress and deficit irrigation on young potted olive cv 'Local-Roghani-Roodbar'. Acta Horticulturae 537 (2), 879-885.

Asik, S.; U. Kaya; G. Camoglu; E. Akkuzu; H. Olmez and M. Avci (2014). Effect of different irrigation levels on the yield and traits of Memecik olive trees (Olea europaea L.) in the Aegean coastal region of Turkey. Journal of Irrigation and Drainage Engineering; 140 (8), 4401- 4025.

Bignami, G.; S. Natali and C. Cammilli (1995). Postharvest irrigation of earli peach cultivars.21st Convegno peschicolo Ravenna, Ittaly, Camere di Cammercio industria Artigianato Agricolture di Ravenna e forli.,235-245.

Bunce, J. A. (2003). Carbon dioxide effects on stomatal responses to the environment and water use by crops under field conditions. J. Oecologia, 140, 1-10

Carmen, B.; R. Sumalan; S. Gadea and S. Vatca (2014). Physiological Indicators Study Involved in Productivity Increasing in Tomato. J. Pro. Environment, 7, 218 - 224.

Chartzoulakis, K.; A. Bosabalidis; A. Patakas and S. Vemmos (2000). Effects of water stress on water relations, gas exchange and leaf structure of olive tree. Acta Horticulturae, 537, 241-247.

Duncan, D.B. (1955). Multiple range and multiple F tests.Biometrics, 11:1 - 24.

Ghatas, Y. and Y. Mohamed (2018). Influence of Mineral, Micro-nutrients and Lithovit on Growth, Oil Productivity and Volatile Oil Constituents of Cymbopogon citruts L. Plants. Middle East J. Agric. Res., 7 (1), 162-174.

Guerfel, M.; O. Baccouri; D. Boujnah; W. Chai and M. Zarrouk (2009). Impacts of water stress on gas exchange, water relations, chlorophyll content and leaf structure in the two main Tunisian olive (Olea europaea L.) cultivars. Scient. Hort., 119: 257-263.

Kumar, V.; V. Guleria and S. Yadav (2013). Gold NANO particle exposure induces growth and yield enhancement in Arabidopsis thaliana. Science of The Total Environment, 641 (1), 462-468.

Lavee, S. and M. wonder (1992). Factors affecting the nature of soil Accumulation in fruit of olive. J. Hort. Sci., 66 (5), 583- 591

Lavee, S.; M. Nashof; M. Wonder and $H$. Harchemesh (1990). The effect of complementary irrigation adds to old olive trees cv Souri on fruit characteristics, yield and oil production. Adv. Hort. Sci., 4 (3), 135-138.

Rapoport, H.; O. Perez-Priego; F. Orgaz and P. Martins (2011). Water deficit effects during olive tree inflorescence and flower development. Acta Horticulturae. (888), 157-162.

Shaheen, M.; A. Hegaz and I. Hmmam (2011). Effect of Water Stress on Vegetative Characteristics and Leaves Chemical Constituents of Some Transplants Olive Cultivars. J. Agric. \& Environ. Sci., 11 (5), 663-670

Tangu, N. A. (2014). Effects on Plant Morphology of drought in olive. Turkish Journal of Agricultural and Natural Sciences, 1, 900:904.

Vrhovnik, I. (2004). Consequences of the drought in 2003 on olive groves in Slovenian Istria.Zbornikreferatov-1-Slovenskega-sadjarskega-kongresa-zednarodnodelezbo Krsko Slovenia 24-26 marec 2004 Del 2, 811-817.

Wu-ShuBiao; G. Collins and M. Sedgley (2002). Sexual compatibility within and between olive cultivars. Journal of Horticultural Science and Biotechnology 77 (6), 665-673

Xiloyannis, C.; B. Dichio bvh v; V. Nuzzo and G. Celano (1999). Defense strategies of olive against water stress. Acta hortic. 4 (3), 423-426 